\title{
Industry 4.0 Perception Regarding to New Developments and New Trends of Industries
}

\author{
Ayşenur Erdi1 $1^{1 *}$ \\ 1*isatanbul Medeniyet University, Department of Business Administration, İstanbul, Türkiye (ORCID: 0000-0002-6413-7482), runesyalidre@ gmail.com
}

(1st International Conference on Applied Engineering and Natural Sciences ICAENS 2021, November 1-3, 2021)

(DOI:10.31590/ejosat.985359)

ATIF/REFERENCE: Erdil, A. (2021). Industry 4.0 Perception Regarding to New Developments and New Trends of Industries. European Journal of Science and Technology, (28), 228-240.

\begin{abstract}
The purpose of this research is to assess the core principles of Industry 4.0, its advantages, literature review, and effective implementation techniques. Searching for published publications may demonstrate recent developments of industries with big data of production system and technology. Industrialization is a catch-all term for a wide range of modern automated systems, data exchanges, and manufacturing technologies. This revolution is a set of ideals comprised of the internet of things, online services, and cyber-physical systems. While the Industry 4.0 model represents a revolution in every aspect, it also delivers numerous breakthroughs, transformations, and adjustments. This research examines the evolution, technical advances, and benefits of Industrial 4.0, gives a brief background to this configuration and its use in industry implementations, and emphasizes the key components influencing successfully businesses. Furthermore, it is underlined those organizational innovations are required for the industry 4.0 revolution in terms of product, process, and business advancements. As a result, a significant deal of innovation is necessary in many sectors before the industry 4.0 model can be implemented. In product, process, business, and operational terms, innovation refers to variety that creates additional value. To that end, the ideas of Industry 4.0 and innovation are described briefly, followed by an examination of innovation through the lens of Industrial 4.0, with illustrations and concepts provided. It is abundantly clear through publications that are being searched those sectors and industries are making use of big data in the production environment and information. This research reflects on the developments of framework-structure in the enviroment of industry for the businesscompanies. The research also contains the aspect-application of the industry 4.0 technology depending on manufacturing system and improvement phases of manufacturing-production of the company. The application via Industry 4.0 technology of a white goods manufacturing company was evaluated on behalf of manufacturing performance and effectiveness of this manufacturing enterprise according to inputs and outputs components of manufacturing system for the analysis in terms of operation management and the business expectation.
\end{abstract}

Keywords: Business, Industry 4.0, Industry-Sector, Innovation, Manufacturing-production, Technology

\section{Yeni Gelişmeler ve Sektörlerin Yeni Trendlerine İlişkin Endüstri 4.0 Yaklaşımı}

$\ddot{O} \mathbf{z}$

$\mathrm{Bu}$ araştırmanın amacı, Endüstri 4.0'ın temel ilkelerini, avantajlarını, literatür taramasını ve etkin uygulama tekniklerini değerlendirmektir. Böylece özellikle üretim sistemi ve teknolojisine ilişkin büyük veriler içeren endüstrilerdeki son gelişmeleri göstermektedir. Sanayileşme, çok çeşitli modern otomatik sistemler, veri alışverişleri ve üretim teknolojileri için kapsamlı bir terimdir. $\mathrm{Bu}$ terim, nesnelerin interneti, çevrimiçi hizmetler ve siber-fiziksel sistemlerden oluşan bir idealler dizisidir. Bu araştırma, endüstriye 4.0'ı evrimini, teknik ilerlemelerini ve faydaların incelemekte, bu yapılandırmaya ve endüstrideki kullanımına bir arka plan oluşturmaktadır. Ayrıca çalışma, endüstrideki uygulamaları ve başarılı işletmeleri etkileyen temel bileşenleri vurgulamaktadır., endüstri 4.0 modeli için ürün, süreç ve iş gelişmeleri açısından organizasyonel yeniliklerin gerekli olduğunun altı çizilmiştir. Endüstri 4.0 modelinin uygulanabilmesi için birçok sektörde önemli ölçüde yenilik yapılması gerekmektedir. Ürün, süreç, iş ve operasyonel terimlerde inovasyon-yenilik, ek değer yaratan çeşitliliği ifade eder. Bu amaçla, çalışmada endüstri 4.0 ve inovasyon fikirleri açıklanmakta, terimsel kavramlarla birlikte endüstri 4.0 merceğinden inovasyon incelemesi yapılmaktadır. $\mathrm{Bu}$ araştırma, işletmeler için sanayi ortamında endüstri 4.0 kapsamında gelişmeleri yansıtmaktadır. Araştırma ayrıca, şirketin üretim sistemine bağlı olarak endüstri 4.0 teknolojisinin uygulama ve imalat-üretiminin iyileştirme aşamalarını içermektedir. Çalışmada, bir beyaz eşya imalat firmasının endüstri 4.0 teknolojisi ile yaptığı uygulama, operasyon yönetimi ve iş beklentilerin analizine yönelik üretim sisteminin girdi ve çıktı bileşenlerine göre bu imalat işletmesinin üretim performansı ve etkinliği değerlendirilmiştir.

Anahtar Kelimeler: İşletme, Endüstri 4.0, Endüstri-sektör, Yenilik, İmalat-üretim, Teknoloji

*Corresponding Author:runesyalidre@gmail.com 


\section{Introduction}

Industry 4.0 is transforming how businesses create, enhance, and advertising their products. Producers are incorporating new digital technology machine learning and business intelligence, and $\mathrm{AI}$ and computational capabilities into their manufacturing structure and materials. These entrepreneur in the future are integrated with modern sensors, computer simulation, and robots to address research questions and make smarter decisions. When intelligence from manufacturing processes is used, it creates more and more revenue (Chiarelloa et al., 2018; Vaidya et al., 2018; Infineon, 2021).

Industry 4.0; It is the name given to the new Industrial Revolution that emerged with the use of Internet of Things (IoT), Big Data and Machine-to-Machine Communication technologies, where business processes are managed with databased scientific methods. With these technologies, in the system architecture where all the equipment in the production area is defined with a unique internet address; A Smart Manufacturing infrastructure will be created where all data produced at any moment in all processes is stored, processed with user-defined formulas and algorithms, turned into meaningful information for process managers through Big Data Analytics, and autonomous production processes are built with rule-based scenarios. In other words, an ideal integration of all hardware and software within company assets is aimed. In order to catch this wave of technology that promises revolutionary changes and unique possibilities under the title of Industry 4.0 comprises data generating points, communication infrastructure that transfers the generated data, big data software that processes and reports the transferred data and a communication network that provides communication between machines should be established (Adolph et al., 2014; Marrr, 2017; Yao et al., 2017; Chiarelloa et al.,2018; Vaidya et al., 2018; Xu et al., 2018; Infineon, 2021).

In order to realize this vision in a holistic approach, products, standards and application practices are developed intensively all over the world. In order to catch the industry 4.0 Revolution, businesses do not have a single roadmap with clear lines in front of them. Companies can only reach Industry 4.0 with the strategies they will determine in line with their own visions, even new business models that this revolution will make possible, and their reason for existence - mission.

\section{Perspective of Industry 4.0}

Industry 4.0 is often known as the fourth industrial revolution, denotes a transitional period in the structure and control of the commercial production process. To comprehend Industry 4.0 , it is necessary to consider the entire process, that mostly working capital management and the origins of the materials and equipment working in diverse forms of smart manufacturing, the reduced flow supply- chain management, and the desired outcome of all industrial production, depending on the number of independent third-party stages and participants: the terminal purchaser. While intelligence from manufacturing operations is integrated with business intelligence via ERP, chain management, customer relations and other business functions, entire new dimensions of accessibility and understanding from widely separated personal details are generated. Although many businesses are also in disapproval with how Smart manufacturing will affect their corporation or are attempting to find the natural ability or real understanding to want to incorporate it for their segments, others are demanding adjustments recently and making preparations for a longer term from which artificial intelligence satisfy their needs and wants (Adolph et al., 2014; Yao et al., 2017; Chiarelloa et al., 2018; Vaidya et al., 2018; Xu et al., 2018; Infineon, 2021).

The First Industrial Revolution emerged at the end of the 18th century with the discovery and use of steam energy and machines working with this energy. The second revolution took place with the invention of machines that developed with the invention of electricity and were faster. The third revolution took place in the 70s, when electricity was replaced by electronics, and production became more efficient thanks to automation and computers (Gerbert et al., 2015; Ozkaya et al., 2021; Vyas, 2018).

\subsection{Innovation Concept}

Innovation is bred in a nurturing way, and that's how they're bred. Innovation is Nova, derived from the Latin verb "of variety". It is not translated into meanings such as innovative, innovative, renewing. Through the Latin verb innovare, which implies to refresh, comes the term "innovation." The definition of the term has remained essentially the same since its inception. A method, a product, or a service can be improved or replaced via innovation. However, in the context of corporations, the word has to be defined. The corporate world is a complicated place, and a definition is necessary. Innovating is the process of renewing and modernizing an industry, product, or service via the application of new methods, the introduction of new technologies, or the establishment of innovative concepts that produce new revenue. When it comes to invention, it means innovating for processes or goods, but innovation goes one step even more and includes putting these ideas into action. An innovative act is accompanied by an associated value strategy that encourages a good consequence. (What is Innovation, 2021; Industrial Revolution Industry 1.0 to Industry 4.0, 2021; Innovation Management, 2021). 


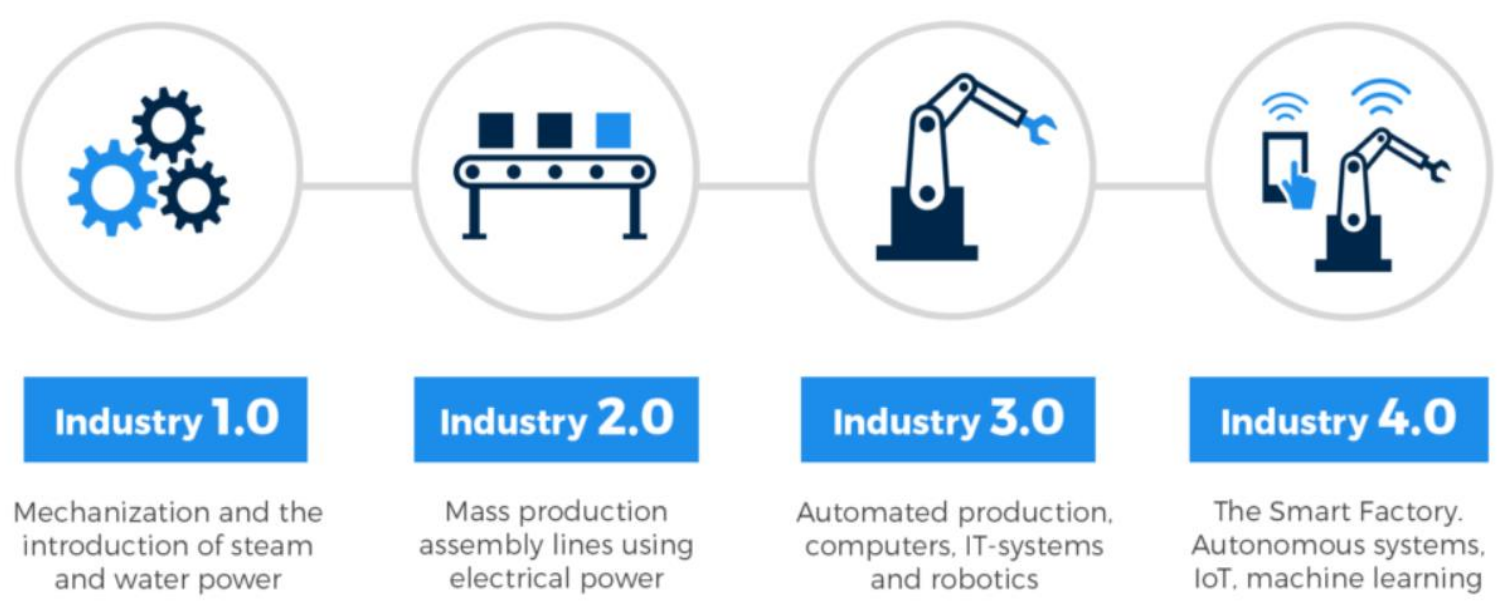

Figure 1. Industrial Revolution Industry 1.0 to Industry 4.0 (Dima, A., https://kfactory.eu/short-history-of-manufacturing-fromindustry-1-0-to-industry-4-0/, Access Date: 21.05.2021)

Through the First Industrialization (Industry 1.0) in the 18th century, rather than always goods getting created by hand, methods were devised that permitted commodities to be constructed by machines. This originated in England in 1760 and eventually made its way to the United States by the end of the 18th century. The First Industrial Revolution signified the transition from an agricultural society and economy driven by machines, and it had a profound influence on sectors such as construction, weaving, bottle, and farming. As a consequence of substantial railroad and communication networks, which provided for speedier transport of people and technologies, the Second Industrial Revolution (Industry 2.0) occurred. With the explosion of the internet, industries were able to create sophisticated manufacturing facilities. The Third Industrial Revolution (Industry 3.0), often known as the Digital Revolution, started in the early of the twentieth century with social networking technologies including the use of consciousness controllers and computers. The mass manufacturing and extensive usage of digital logic, Semiconductor electronics, and embedded system chips, as well as their derivative technologies such as computers, microcontrollers, digital mobile phones, and the World wide web, is the primary focus of this period. Conventional manufacturing and commercial practices have been altered as a result of technology advancements. Essentially, we may argue that the technological age turned conventional knowledge into a digital system. Recent times, everyone is talking about Industry 4.0 , which is an association of physical resources and enhanced digitalization such as the Internet of Things (IoT), Artificial Intelligence (AI), robots, drones, autonomous driving, 3D printing, cloud technology, and others that are associated and have the skills to interact, analyze, and operate. Organizations that implement Industry 4.0 seem to be more adaptable, adaptive, and sophisticated, and hence better positioned to make bandwidth choices (Duxbury, 2012; Adolph et al., 2014; Bauer et al., 2015; Gerbert et al., 2015; Vyas, 2018; Dima, 2021; Industrial Revolution Industry 1.0 to Industry 4.0, 2021; see figure 2).

e-ISSN:2148-2683
Industry 4.0 is a concept introduced at a technology fair in Germany in 2011. It is also seen that this concept is explained as the 4th Industrial Revolution in some sources. Industry 4.0 is known as a German project. The reason for Germany to initiate such a project is the opportunities that China has in the field of production, which has seriously shaken the European states economically. In the face of this superiority of China, countries such as Germany, America and Japan have turned to the industry 4.0 project. The aim of this project is to carry out all vital mechanisms together with information technologies. This project is a set of three-stage systems, namely the internet of things, the internet of services and cyber-physical systems. While Industry 4.0 adopts an extremely fast and practical production approach, it also aims to prevent waste while making this production. This application, which is planned to bring a new order to the world's life, will be equipped with smart equipment and all systems will work in an integrated manner. It is planned that this system will be fully implemented within 20 years at the latest. With this system, which will completely restructure the production and consumption life, this distribution, which can be replaced by rich-poor countries, will change. There will be gaps in income distribution between countries. There are not enough resources available on this subject. Each country has a research unit established in this field. Although this project seems to affect only the factories and production life, it will indirectly affect our social lives in many positive and negative ways (Schmidt et al., 2015; Gerbert et al., 2015; Gartner Group, 2017; Cedeño et al., 2018; Duysak et al., 2021 Vaidya et al., 2018).

Innovation is considered as the successful implementation of productive ideas and the acceptance of these ideas by various stakeholders in their ecosystem. The word innovation is derived from the Latin verb "innovatus". Innovatus means to change, to innovate, to renew. According to Christopher Freeman; Invention, innovation and innovation are different concepts. While invention is a blueprint, idea or model for a new or improved tool, method or system, innovation is the economic use of new production, method, system or tools that include 
value creation processes, that is, their conversion into economic value. The following situation can be given as an example to reveal the difference between innovation and invention: When the sewing machine is mentioned, the Singer brand developed by Isaac Singer comes to mind. But the sewing machine was actually invented by Elias Howe in 1846. Isaac Singer has transformed this sewing machine into innovation by adding economic value (Duxbury, 2012; Chiarelloa et al., 2018; Douaioui et al., 2018; What is Innovation, 2021; Innovation Management, 2021).

Depending on the consideration of some important concepts in this concept, these are interoperability, that is, an environment where people will work in harmony, virtualization, that is, the virtualization of smart factories by copying, autonomous management is the authority of the system in question to make independent decisions within the smart factory, all data collected in real-time can be processed quickly. way it can be analyzed. In other principles, research can refer to service orientation and modularity (Gerbert et al., 2015; Chiarelloa et al., 2018). Types of innovation are presented as below (OECD, (2005). Oslo
Kllavuzu): product innovation, process innovation, marketing innovation and organizational innovation.

- Product innovation can be the use of new information or technologies, or the opening of existing knowledge and technologies to new uses or a combination of these.

- Organizational innovation, on the other hand, is the application of an effective and new organizational method and approach in the commercial practices, external relations and management processes of institutions.

- Process innovation is defined as the creation of a significantly improved and new method of delivery or production, the use of equipment, tools and information in technology that will enable to produce existing products faster, with better quality and at lower cost.

- Marketing innovation is the implementation of a new marketing method that involves significant changes in product placement, product promotion, product pricing, product design or packaging.

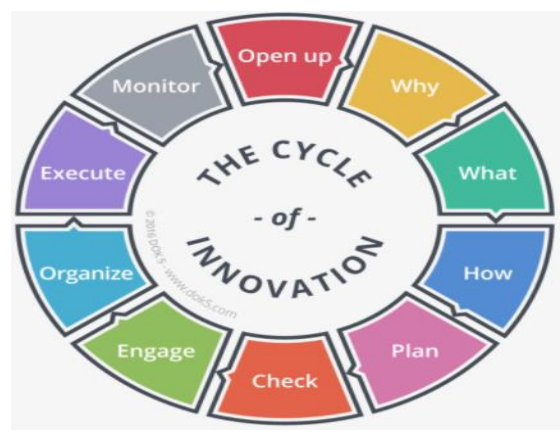

Figure 2. Cycle of Innovation (The Cycle of Innovation, https://dok5.nl/en/the-cycle-of-innovation/, Access Date: 21.05.2021)

The Cycle of Invention begins with the idea that technology is no longer performed in glorious seclusion in institutions, but rather in cooperation with other individuals (see figure 2); (i). With that of the natural ecosystems help, user may seek to create into the actual reasons why you need to develop (ii). Assuming individuals understand why, guests could determine what the minimum required of entrepreneurship would offer and when it should give it (iii). Users explore how you will accomplish these innovative objectives (iv). And then devise a strategy to make it a reality (v). This involves validating the assumptions that you developed in earlier phases (vi). Following that, you invite all stakeholders in your eco-system to assist (vii). Users create a successful organization based on the innovation objectives and plan. (viii). Users establish an organizational culture and implement a continually developing, business environment centered on approach focusing on someone innovation objectives and strategies (ix). The Cycle's last approach relies on monitoring performance, gathering insights, and changing direction (x). Then it's appropriate to gaze outdoors and restart the Cycle (The Cycle of Innovation, 2021; Innovation Cycle, 2021).

\subsection{Industry 4.0 and Innovation}

Industry 4.0 represents the transition to an innovation-based economy with information, data and IoT. opens. Industry 4.0 allows to respond to customer needs faster than possible. It forms the basis for the adoption of new business models, production processes and other innovations by increasing the flexibility, speed, efficiency and quality of the production process. Innovative developments in the field of communication, internet and information technologies are the basic building blocks of the industry 4.0 revolution. In addition to the benefits of the industry 4.0 revolution, there are some disadvantages in terms of social, environmental, political, legal, economic and technical issues. In order to avoid these disadvantages, it is necessary to design innovation-based production processes and develop new service-oriented business models. With the continuous development of technology in production, the innovative production approach has shown itself. This view reveals the link between Industry 4.0 and innovation. Because Industry 4.0 is closely related to innovation as it is an industrial revolution that includes high technological development and 
transformation. With Industry, innovative, efficient and errorfree products have started to appear, and innovations in production have increased with smart factories (Lee, I and Lee, K., 2015; Vaidya et al., 2018; Xu et al., 2018).

A model of a micro-intelligent factory system is being built in Kaiserslautern, Germany. Soap bottles are shown as an example to form an idea of how devices and products in this factory will communicate. The colors on the bottles can be recognized with the special RFIF labels on the bottles. This is one of the simplest examples of cyber-physical communication. As a result of some developments that started with Industry 4.0, changes were not experienced only in the production departments of the companies. This development has been instrumental in keeping up with the change in different departments that are efficient in all stages affecting production, take into account customer requests, and provide timely and perfect service. Many smart systems such as WIFI, RFID, POS devices, which were used before this development, but we can say that they are all used for a common purpose today, are collected in some processes such as producing, purchasing and marketing all kinds of data related to companies. In this way, the issue of how to transform many large-scale data collected in cloud systems into information has become a very important issue. This situation has created the field of data science, which has become widespread rapidly and has made it necessary to employ data scientists in the departments of the organizations. Concepts such as data mining, artificial intelligence, machine learning, which are sub-branches of data science and included in business intelligence, which support decision-making processes in all matters related to institutions, are frequently used. However, with Industry 4.0, the importance of these concepts has been understood much more and thus their importance has increased (Duxbury, 2012; Gerbert et al.,2015; Schmidt et al., 2015; Morrar et al., 2017; Chiarelloa et al., 2018; Xu et al., 2018; Cedeño et al., 2018).

\section{Literature Review}

\subsection{Findings from the Literature Review}

The 4th Industrial Revolution, that is now underway, poses a range of electronic, structural, and administrative difficulties for manufacturing businesses. Significant changes in the sphere of work are predicted as a result of the application of new technologies and the transformation of processes, and future production systems will necessitate new capabilities from people. Processes are projected to become more accessible, decentralized, and less structured as working environment becomes more adaptable in time and place (Picot and Neuburger, 2014; Horváth and Szabó, 2019).

Industry has become increasingly willing to participate in the development of new technologies to maintain organizational competitive advantages and encourage them to make adjustments to sequentially changing external environment such as during out lifespan, interpretations, and modifying customer expectation, in alignment with the anticipated changes (Spath et al.,2013; Adolph et al., 2014; Lasi et al., 2014; Bauer et al., 2015; Horváth and Szabó, 2019).

There is a scarcity of broad field research on Industry 4.0 and the productivity of Malaysian manufacturing businesses. The article briefly explains the major technologies of Industry 4.0 and rates them in terms of absolute frequency as indicated in the literature. The research topics that have been established involve the link between productivity and Industry 4.0 technology. Productivity is a critical component of manufacturing businesses' competitiveness. As a result, prior to implementing new manufacturing technologies, Malaysian manufacturing businesses must do research on the link between Industry 4.0 technology and productivity. Throughout response to numerous approaches, this theoretical study aims to apply framework for future research on the link involving Industry 4.0 technology and Local construction business productivity (Karl and Nadarajah, 2019). Besides from higher efficiency, other projected advantages include streamlining automation processes and enhancing product customization. A platform for the beneficial adverse effects of Industry 4.0 on sustainability is also being created. The development of a system of thought for the application of Industry 4.0 in multinational corporations (MNCs) has begun. The emphasis is on the specific problems of integrating Industry 4.0 in an MNC's company operations of research \& innovation, vision realization, technology management, and supply chain (Dalenogare et al., 2018; Kamble et al., 2018; Telukdarie et al., 2018).

Alborzi and Khanbabaei determined the behavior of customers by creating customer credit scores by analyzing the usage information of bank cards belonging to customers of a bank in Iran. They have also succeeded in dividing customers into classes with the approach of artificial neural networks. In 2016, Culotta and Cutler analyzed customers' brand perceptions in a cost-free and effortless way using the data they collected from social media. In this study, in which they used the techniques of data mining, they did not analyze the content created by social media users, but instead analyzed the networks created by the customers of this brand. Ghazavi and Lotfi also offer some ideas to authorized people about shelf design by using the mathematical formula they developed for customers to navigate around the store in 2016.Artificial intelligence techniques were used in this study. It has been understood that the online comments made by the customers about the easy decision making of the companies during the development of new products can be transformed into useful information with an analysis. Kaneko and Yada, on the other hand, using the data on shopping transactions and browsing in the store belonging to a group of supermarket customers, they found that the customers buy more products as they browse through the store. This collected data is the data revealed by matching the customers' POS data with an RFID tag attached to the shopping carts that customers use while shopping (Alborzi and Khanbabaei, 2016; Culotta and Cutler, 2016; Ghazavi and Lotfi, 2016; Kaneko and Yada, 2016).

Manufacturing, as researchers perceive it, is entering a period. New industrial innovations and creative ways of participating in industry to achieve business performance are always on the horizon. As a result of past study findings, a new issue is being posed, such as: how could industrial production grow increasingly competitive, adaptable, and the ecological consequences required to support a corporation's sustainable development achievement? Sustainable construction includes optimizing processes in order to reduce negative consequences and remove possible challenges to generate wealth (Cedeño et al., 2018; Onu and Mbohwa, 2019; Onu and Mbohwa, 2019). The current study of the researchers investigates the potential and difficulties of 4IR deployment for corporate social responsibility in order to improve SMEs' sustainable companies and policy decisions to boost techno-innovativeness, especially 
in Developing countries. This study seeks to assist corporate entrepreneurship professionals and policy campaign managers in commercial and public cooperatives in developing industrial alternatives that would support the incorporation of information innovations and long-term value chain enterprise (Cedeño et al., 2018; Onu and Mbohwa, 2019; Onu and Mbohwa, 2019).

In another study conducted in 2016, customer comments were analyzed to support the decision-making processes of product designers. During this analysis, similar comments on an online shopping site and sentiment analysis of these comments were included. The aim of this study was to shape the designs of the products according to the needs of the customers. In this study, in which the comments on many models of many mobile phone brands were examined, customers mostly commented on the features of the phones such as batteries, screens and memory. These analyzed comments are also grouped as positive and negative comments. Rodrigues and Ferreiea, on the other hand, wrote an algorithm by dividing the customers of a perfumery chain into three groups, and accordingly, the products suitable for these groups were suggested to them. Weng, on the other hand, stated that the support value of a product released later on with another product that was released before it would be low. In this way, he wrote a new algorithm for the analysis of the coexistence of products entering the market at different times (Rodrigues and Ferreira, 2016; Weng, 2016).

The study of Kamble et al. (2018) aims to identify the main hurdles to Industry 4.0 implementation in the Manufacturing and services sector and suggests how industry professionals and decision makers may make significant progress to effective Industry 4.0 implementation. The study technique was a combination of interpretative structural modeling (ISM) and fuzzy MICMAC (Matriced' Impacts Croise s Multiplication Applique e an un Classement) assessment. This study contains interpretative structural modeling (ISM) to create linkages between obstacles and uses fuzzy MICMAC (Matriced' Impacts Croise s Multiplication Applique e an un Classement) parameter controls the motivating and reliant potential of obstacles (Kamble et al., 2018).

Including its understanding of the term, Industry 4.0 is accessible to any type of organization and any size of organization, including SMEs. Nonetheless, due to the complexity and specific resources required for this transformation, SMEs will naturally face difficulties in adopting the difficulties associated with sustainable development; consequently, any methodologies and/or tools that aid in trying to guide and standardizing its incorporation are greatly appreciated. The research previously includes various approaches to comprehend the conceptual framework and actions to follow, as well as development plans to help strategic decision- making processes (Kagerman and Johannes, 2013; Lichblau et al., 2015; Schumacher et al., 2016; Proença and Borbinha, 2016; Ganzarain and Errasti, 2016; Amaral et al., 2019).

The importance of the issue starts with an emergence of Industry 4.0 and its significance, then moves on to what performance measures are and why they are essential in this environment. A study of the research on Industry 4.0 existing resources is conducted, followed by an assessment of their appropriateness for SMEs. In the third portion of the research, a framework for SMEs to develop and execute Industry 4.0 is suggested, consisting of a set of activities that SMEs would contemplate if they want to survive on the route to Industry 4.0 (Kagerman and Johannes, 2013; Lichblau et al., 2015; Schumacher et al., 2016; Proença and Borbinha, 2016; Ganzarain and Errasti, 2016; Amaral et al., 2019). Tanaka developing a work with his analysis in 2017 has been classified according to their importance to customers of a supermarket chain in Japan. The Tsai study, on the other hand, revealed an intelligent system that predicts the purchasing behavior of customers. This system in question consists of four main contents.

Singh and Tucker (2017) show that reviews about products on the Internet play an important role in customers' decision to purchase. For this purpose, using the machine learning approach, it automatically divided the comments made by the customers into two groups (Tanaka et al., 2017).

In 2018, Griva groups customers according to their visits to the store, using clustering and association rules, which are basic data mining techniques, and sales data. This study, unlike the previous ones, is not based on the products that a customer buys in one visit, but according to the products he buys in many visits. In this way, the purpose of the last visit of the customer can be determined. In 2018, Vincent classified the data of a group of customers using data mining techniques in order to achieve success in fashion design. With the results that emerged as a result of this, it was understood what kind of design the customers wanted in their new orders and gave ideas to the companies on this subject (Griva et al., 2018; Vincent et al., 2018).

Industry 4.0 is driving aspects of organizational models, resulting in the creation of modern developments as well as the retirement of current professions that will be replaced by smart machines and gadgets. The start of the Fourth Industrial Revolution is characterized as developing nations, which may take some years to execute. Skills, talents, and understanding in the workforce would all need to be improved. The research of Holubčík et al. (2021) provides insights in an information and decision-making system for the whole supply chain. The first step is to acquire information. During first step, an in-depth examination of manufacturing and production regulations was undertaken in close collaboration with production workers considered in the process approach (Holubčík et al., 2021). In Bravi and Murmura' study, barrier arises from the fact that the consequences cannot be thoroughly representative of the overall economic situation due with the use of theoretical framework, both descriptive and analytical; on the other hand, the additional benefit is accurately of just being willing to investigate in depth some relevant positive characteristics, which survey method frequently completely ignores. Future study might expand on the findings by employing a quantitative data collecting technique on a wider sample of Planned to make in Italy manufacturing businesses, engaging additional essential stakeholders such as employees, distributors, collaborators, and establishments (Bravi and Murmura, 2021).

To investigate environmental implications, a methodology product or service, procedure, and structure sustainability measurement groupings is used. The research of Enyoghasi and Badurdeen (2021) shows that the research is still constrained in encouraging innovation for profile and performance report at differing stages incorporating Enterprise systems; the implications of Emerging technologies on many requirements regarding the brand, operation, or system level sustainable 
development has not yet been investigated. The performance comparison and complex structural are utilized to identify future research objectives and possibilities for utilizing Industry 4.0 technology for even more sustainable production. The consequences for enterprise of establishing a framework (Enyoghasi and Badurdeen, 2021). The results of the study of Enyoghasi and Badurdeen (2021) may be used to determine and propose implications of the findings with the use, sustainability, and closing governance of productive assets that should be carried out (Tseng et al., 2018). These suggestions encourage the research establishment to use technical advancements in Industry 4.0 to foster close-loop, 6R-based commodity movements in order to reap advantages from many TBL viewpoints (Enyoghasi and Badurdeen, 2021).

Researchers present a framework for describing and categorizing Industry 4.0 technologies, which influence both manufacturing and product development. The suggested framework is required to serve as the foundation for a systematic and consistent definition of present technology, as well as to differentiate the associated operations together within product development process. The main concept is to combine current models of cyber-physical production systems with known descriptions of key stages of the innovation building and improving a framework for defining Industry 4.0 advancements in manufacturing and product generation. The broad usage of the phrase "Industry 4.0" contributes to a muddled comprehension and a plethora of definitions. The broad usage of the phrase "Industry 4.0" results in a muddled comprehension and a plethora of descriptions of applicable technologies. Additionally, traditional models and approaches for describing the similarities and differences of Emerging technologies frequently focus on production systems and do not provide a foundation for understanding innovations that encompass literally the entire product development process (Inkermann et al., 2019).

The purpose of Vishal and Vinodh 's study (2021) is to identify significant difficulties associated with Industry 4.0 adoption in the automobile industry and to analyze the identified challenges and obstacles to prioritize them for systematic implementation in Indian automobile industry (Vishal and Vinodh, 2021). This finding emphasizes the need of laying a technology foundation as well as focusing on increasing labor abilities in order to promote 14.0 implementation. As a result, it is probably encouraged that, prior to implementing Industry.0, Indian automotive businesses should first create rules for Industry.0 technical development in the production shop. The study's conclusions helped practitioners to take suitable actions toward Industry 4.0 commercialization (Vishal and Vinodh, 2021).In other study, the researcher evaluates the potential implications of the Fourth Industrial Revolution on labor markets. The implications, possibilities, and difficulties of the operation are explored in a better perspective through an analysis of the report and assessment of recent technologies with Industry 4.0 .

This issue is typically associated through the use of robotics in industry and manufacturing, three-dimensional printing, the adoption of new technologies, and big data research. These improvements, also based on the Internet of Things, the Instant messaging of Everything, or the Industrial Internet, are distinguished from industrial age by four distinctive characteristics: Cyber-Physical Systems (CPS), Big Data and Digital Information Exchange, Smart Robots, and Digital Industrialisation. As a result, smart factories will automatically e-ISSN:2148-2683 adjust production circumstances to current circumstances and coordinate manufacturing plans based on ordering demarcation (Kurt, 2019). Implementing such innovative technology provides the National industry a competitive advantage (e.g., greater performance across more up-to-date data, faster service supply). Integrated and interconnected platforms, goods, and operations provide greater product quality while using less resources. Furthermore, digitalization is generating innovative business models for manufacturing. On the other hand, the industry is undergoing transition as a result of shifting border circumstances. Expanding internationalization, more unpredictable product life phases, growing economy, global warming, and population change are some of these factors (Abele and Reinhart, 2011; Bruhn and Hadwich, 2017; Niemeyer et al., 2020).

The industry 4.0 is commonly referred to as Business sector 4.0. In 2011, the phrase "Industry 4.0" has been coined in Central europe as a proposal to change model of European industrial policy. The term smart industry, often known as "Industry 4.0," refers to the technical progression from business applications to Cyber Physical Systems (CPS). The confluence and application of nine modern technological innovations constitutes Industry 4.0. Intelligent automation, manufacturing technology, mixed reality, artificial intelligence, operational excellence, internet of things, cloud computing services (CCS), cyber security and Big Data, and business intelligence are examples. Cloud computing and CPS are inextricably linked. Because CPS will create a significant quantity of data, known as big data, in order to increase system scalability, security, and efficiency. Big data is defined as "a connection that discreetly links and combines the real environment, human civilization, and cyberspace (Jin et al., 2015; Xu et al., 2018).

Internet of technology (IoT) offers a great potential for realtime collecting data, delivering meaningful information, and predictive analysis at a cheap cost, while also entering a new horizon of a transaction strategy for producing additional value. Combining Big data, a huge spectrum of information related via IoT may deliver personalized services (Trappey et al., 2017; Aheleroff et al., 2020). This research intends to address the voids by converting traditional electronic gadgets into IoT-enabled intelligent sensors that can be integrated into a home automation system. A manufacturing process shows how to transform traditional equipment into smart products and systems (SPS) by leveraging cutting-edge Lean manufacturing techniques (Aheleroff et al., 2020). In a distributed world, System facilitates the transformation of data into intelligence, understanding, and knowledge and understanding (DIKW) for real-time observation, alerting, and condition monitoring at the product and service levels (Zheng et al., 2019). This report (Aheleroff et al., 2020) indicates on an industry-led case study on converting a conventional equipment into an intelligent and Internet - of things utility in order to address the four research objectives listed below. - How can traditional household appliances be converted into smart devices? - How should continuous integration be addressed via a secure wireless connection? • How can consumers be empowered with real-time monitoring and control of electronic gadgets? - What innovations are necessary to make standard equipment smart?

The primary objective of Nakagawa et al. (2021) is to continuously evaluate Industry 4.0 reference designs and determine their appropriateness for enabling Industry 4.0 processes and solutions. We did this by conducting extensive 
study on these designs and extensively analyzing and characterizing them. Researchers also discuss its application and the technology solutions that may aid in their execution (Nakagawa et al., 2021). Implementing Industry 4.0 principles in businesses/factories remains a significant issue. A complete absence of big achievement technologies and a shortage of deeper negotiated centralization that reference architectures would need have hampered such development, not only in large innovation manufacturing plants such as the automotive industry, as well as in small and medium-sized enterprises (SME), in which the biggest improvement respectively Industry 4.0 operating cost and its advantages is unidentified (Nakagawa et al., 2021). Industry 4.0 provides a platform for the manufacturing companies to allowing covered operations and increase the intelligence of its whole supply chain. Manufacturing technology, also known as the information technology of manufacturing, underlines the quantity produced, evaluation, making preparations, and rearrangement of good or service, operation, and access to resources using numerous different modern technologies to enhance design process, function visualization, and prototype industrial production. The objectives of the investigation contribute significantly to the field. Initially, researchers investigate why supply chain relationship investment may assist businesses in improving their business results using corporate green management in digital manufacturing, as driven by Industry 4.0. Furthermore, researchers broaden the methodological approach of environmental building partially covered supply chain relationship capital as more than just a driver. Lastly, researchers broaden the scope of connection capital to include supply chains, expanding the range of social capital scenarios that may be used. These finding provides practical advice for manufacturing businesses looking to increase economic rewards by optimizing existing supply chain relationships (Yu et al., 2021).

\subsection{What does Industry 4.0 include?}

Industry 4.0 is a broad description of a structure and relates to a tripod-like structure. Internet of Things, Internet of Services, and Cyber-Physical Systems are the foundations of the business. Devices will be able to interact with each other, evaluate data, and inform people when required in Industry 4.0, which is founded on the premise that systems are in contact with each other. Sensors will allow machines to connect wirelessly with each other. Meanwhile, the system will run at a lower cost, generate more quickly, and produce very little waste. Despite being smaller, these systems will deliver better results. Industry 4.0 is centered around robots. In addition to managing and evaluating machines and evaluating production data, these robots also make other production-related choices. Some authors refer to these manufacturing facilities as "dark factories" since they are lightless and unattended. Apart from that, 3D printers represent a new dimension in the Industrial Revolution 4. It will be possible to manufacture everything you need at home with a single touch, eliminating the need for huge corporations. When Industry 4.0 is currently functional, societal concerns would also develop. This must not be ignored. Joblessness might be the first phrase that comes to mind immediately. In addition to reshaping production and consumption, this approach would then create economic inequality throughout rich and poor nations. Industry 4.0 is expected to be completely implemented in 20 years or less (Chiarelloa et al., 2018; Vaidya et al., 2018; De Sousa Jabbour et al., 2018; Infineon, 2019).
The data collected by industries is expressed in huge dimensions today due to reasons such as the closure of small businesses in the retail sector, which is the most widely known area of marketing, the policies to increase the number of multinational stores, and the desire of consumers to meet their increasing needs from these retail chains. The fact that manufacturers establish relationships with retailers through their activities such as stock applications with smart systems and logistics solutions increases the size of the collected data much more. In order to compete with other businesses, businesses also act to serve their customers better. For this purpose, the retail sector, which moves, collects data with systems such as smart sensors and WIFI, as well as POS systems, and started to create their own systems by collecting this data in their own cloud systems. In addition, these companies can also obtain many more data such as comments on social media and consumer blogs, and data from visitors to the company's website. With this data they have accumulated, they keep their customers under constant surveillance and make useful inferences from this data and make various analyzes. It can be said that thanks to Industry 4.0 , it is necessary to constantly monitor and analyze the attitudes and behaviors of the customers in order to reflect the instant data collected from the customers to the production processes as quickly as possible. Thanks to Industry 4.0, very large-scale data is collected by companies in the processes such as storage, logistics, in-store, marketing and sale of a product, starting from the design process, and even in the use of the customer. Although similar data are analyzed quickly by companies, they are transmitted to all departments in the business, especially production departments, and the company has the capacity to respond quickly to these requests and demands of the customer. According to a technology report published by Gartner, it is predicted that the use of data processing and analysis systems will increase in many areas with marketing in the next five years, and technologies such as data mining and artificial intelligence will be in the top five among the technological fields of activity (Duxbury, 2012; Lee, I and Lee, K., 2015; Gerbert et al.,2015; Morrar et al., 2017; MAGG4, 2018; Douaioui et al., 2018; Chiarelloa et al., 2018; De Sousa Jabbour et al., 2018; Infineon, 2019).

\section{Material and Method}

\subsection{Industry 4.0 and Its Current Applications}

Industry 4.0 is defined as the industrial revolution 4.0, which will support from technological transformation in industrial processes and material science, cutting-edge modern communications, service-orientation of experience and understanding automated manufacturing industries, and developing methods of electronically meeting the needs of customers via technological advances of businesses and interactions (Roblek et al., 2016; Yao et al., 2017; Tiwari and Khan, 2020). Industry 4.0, a corporate strategic initiative, aims to create production facilities in which various technological innovations such as business intelligence, the internet - of things, printing technology, artificial intelligence, computing, and intelligent machines are used to accomplish computer crimes structures (CPS) and opportunity to contact, resulting in economically, environmentally, and sustainable development manufacturing industries (Lasi et al., 2014; LeeI and Lee K., 2015; Schmidt et al., 2015; Bahrin et al., 2016; Kamble et al., 2018). 
It is seen that many innovative technologies have emerged that paved the way for the Industry 4.0 revolution. These technologies, which were given under the headings in the previous parts of the study, are briefly explained below (Marrr, 2017; Chiarelloa et al., 2018; Vaidya et al., 2018; Xu et al., 2018; Infineon, 2021).

(i) Big Data and Analytics: Collecting and comprehensive evaluation of data from many different sources (production equipment and systems, as well as business and customer management systems), standardizing it to support real-time decision making.

(ii) Autonomous Robots: Robots used to tackle complex tasks are in the future of industry, interacting with each other, working

\subsection{Application of This Study}

With Industry 4.0, the factory has started to benefit from all kinds of blessings of technology. A production-manufacturing line that does not require manpower, machines that communicate with each other without the need for human beings, a system that allows to start and stop production from outside the factory, error-free mass production, changes made on products with small software, data collection in a single center and instant elimination of errors. offered to businesses. In general, it consists of 3 structures; internet of things, internet of services, cyber-physical systems. It enables the monitoring of physical transactions with cyber-physical systems, real-time communication of people and cyber-physical systems with the Internet of Things, and the provision of internal and crossservices with the Internet of Services.

As a business growth strategy, it aims to make it more competitive in the field of production with industry 4.0. But how will it measure the firm's competitiveness? One of the most common ways to do this is by measuring efficiency. Efficiency measures how well resources are used. It is calculated as the ratio of output (goods and services) to inputs (labor and materials). As the company uses its resources more effectively with industry 4.0 technology, it will be more efficient.

When assessing efficiency and defining performance criteria, the enterprises must also consider their market competitive strategy. Efficiency of a company may be evaluated in units generated over time as a firm that competes on speed. A business competing on a cost basis, on the other hand, should with and learning from humans in a more autonomous, flexible and collaborative manner. For example, Kuka, a European robot manufacturer, offers autonomous robots that interact with each other.

(iii) Simulation: In the engineering phase, 3D simulations of products, materials and manufacturing processes are already used, but real-time data is used to create a virtual model that can include the physical world, machines, products and people. Thus, the "digital twin" enables operators to test and optimize machine settings for the next product in the virtual world before the physical change, thereby reducing machine setup times and increasing quality (Marrr, 2017; Chiarelloa et al.,2018; Vaidya et al., 2018; Xu et al., 2018; Infineon, 2021).

assess its efficiency in terms of input costs (such as labor, materials, overheads). It is critical that the efficiency measure informs us about how well we are performing in relation with competitive priority of the enterprise.

In this part of the research, application via Industry 4.0 technology of a business was evaluated on behalf of manufacturing performance and effectiveness of this manufacturing enterprise due to inputs and outputs components of manufacturing system for the analysis in terms of management, satisfaction, with the business expectation for a XYZ Enterprise located in Marmara Region in Turkey in white goods manufacturing sector. The manufacturing flow diagram was examined to support the development of the workflow for the manufacturing department of this white goods manufacturing enterprise-company

Because of Industry 4.0 technology, efficiency is primarily measured via performance. Innovation, work effectiveness, and productivity are long-term prerequisites for a company's continued operation. It may just be switched on if it produces a high level of production, dependability, and performance. Efficiency is generally the most essential indicator of performance in businesses since it directly demonstrates physical and monetary benefits. However, subjectively output factors do not appear in effectiveness. The objective is to improve effectiveness and lowering overall expenses. To evaluate this modification, output rates should be monitored. The performance evaluation ratios are used for this manufacturing enterprise using Industry 4.0 technology, as shown in Table 1.

Table 1. Productivity Analysis-The Results of Productivity of XYZ Manufacturing Enterprise

\begin{tabular}{|c|l|l|l|l|l|}
\hline & & $\mathbf{2 0 2 0}$ & $\mathbf{2 0 2 1}$ & $\mathbf{2 0 2 2}$ & $\mathbf{2 0 2 3}$ \\
\hline \multirow{3}{*}{ Output } & $\begin{array}{l}\text { Sales Value } \\
\text { of Products }\end{array}$ & 160.000 & 255.000 & 480.000 & 580.000 \\
\hline \multirow{4}{*}{ Input } & Labor & 58.000 & 85.000 & 175.000 & 205.000 \\
\cline { 2 - 6 } & Raw material & 12.000 & 10.000 & 25.000 & 37.700 \\
\cline { 2 - 6 } & & 15.000 & 17.000 & 27.000 & 38.000 \\
\cline { 2 - 6 } & Others & 30.000 & 65.000 & 115.700 & 135.000 \\
\hline
\end{tabular}

Table 2. Labor force, raw material and total Efficiency-Productivity Rates of XYZ Manufacturing Enterprise

\begin{tabular}{|l|l|l|l|l|}
\hline & 2020 & 2021 & 2022 & 2023 \\
\hline
\end{tabular}


EuropeanJournal of ScienceandTechnology

\begin{tabular}{|c|c|c|c|c|}
\hline $\begin{array}{c}\text { Labor } \\
\text { Efficiency }\end{array}$ & $160000 / 58.000=2,75$ & 3,0000 & 2,7429 & 2,8293 \\
\hline $\begin{array}{c}\text { Raw } \\
\text { material } \\
\text { Efficiency }\end{array}$ & $160.000 / 12.000=13,333$ & 8,5000 & 19,2000 & 15,3846 \\
\hline $\begin{array}{c}\text { Total } \\
\text { Efficiency }\end{array}$ & $160000 / 115.000=1,391$ & 1,4407 & 1,4006 & 1,3952 \\
\hline
\end{tabular}

Labor force, raw material and total productivity- Efficiency rates between 2020 and 2023 are as above Table 2 .

Productivity Index = current period-year efficiency / baseyear efficiency
The formula (1) is calculated Labor force, raw material and total Efficiency-Productivity Rates based on the year 2020, the productivity change in 2023 as an index.

(1)

Table 3. Efficiency- Labor Productivity, Raw Material Productivity and Total Productivity Index

\begin{tabular}{|l|l|l|l|}
\hline $\begin{array}{l}\text { Labor } \\
\text { Productivity } \\
\text { Index }\end{array}$ & $2,829 / 2,75=1,028$ & $2,8 \%$ & $\begin{array}{l}\text { Increase } \\
\text { Amount }\end{array}$ \\
\hline $\begin{array}{l}\text { Raw } \\
\text { Material } \\
\text { Productivity } \\
\text { Index }\end{array}$ & $15,384 / 13,333=1,153$ & $15,3 \%$ & $\begin{array}{l}\text { Increase } \\
\text { Amount }\end{array}$ \\
\hline $\begin{array}{l}\text { Total } \\
\text { Productivity } \\
\text { Index }\end{array}$ & $1,395 / 1,391=1,0028$ & $0,28 \%$ & $\begin{array}{l}\text { Increase } \\
\text { Amount }\end{array}$ \\
\hline
\end{tabular}

Based on 2020, the labor productivity change in 2023 (see Table 3) increased by $2,8 \%$. Based on 2020, the raw material productivity changes in 2023 increased by $15,3 \%$ rate. Based on 2020 , the total productivity change index in 2023 increased by $0,28 \%$.

\section{Results and Comments}

Most major manufacturers currently recognize that cost is only one factor in determining efficiency. In fact, the use of costs as a gauge of efficiency is highly contested. This is due in part to the belief that expenses are inextricably linked to other activities such as productivity and quality. Manufacturing costs, in perspective, are not the only clearly connected aspect to customer wants. For decades, cost reductions have not resulted in simultaneous quality and delivery improvements, which have been nearly ubiquitous and, in some cases, the sole aim of production efficiency. As a result, it is necessary to obtain a proper and useful data set for a healthy analysis of job postings. The most important part here is the creation of a proper data set. Otherwise, no matter how good an analysis program is, it should not be expected to yield healthy results. When working with a proper data set, the frequency of terms among the most soughtafter job postings and the affinities and connections between these job postings are extracted. Although it is not possible to reach a definite conclusion thanks to this type of analysis, it can be possible to make an inference about the direction in which the job advertisements to be given in the future are showing, thanks to the current job postings. Data mining includes studies to extract meaningful information from this data set. With data mining analysis, business profiles can be clustered and information about trends can be obtained. The important point is to catch the relationship between words and phrases by using them. Thus, occupational groups are categorized. Today, following such innovations has gone beyond being a choice or preference and has become a necessity. The technology to be produced with these innovations appears in many fields from defense industry to food, from construction to health sector. Many new approaches are now in the middle of our lives, from the interfaces we use while shopping on the Internet or the big data that collects our footprints while surfing the Internet, to the innovative innovations in which robots operate in many areas. In addition, many startups today prefer to emerge through such innovative resources that are digitalized and combined with industry 4.0. At the same time, an enterprise, company and even public institutions should not stay away from such innovations. Because the innovative cycle is not a cycle that will ever stop. All products that will always continue and the new ones survive, while the old, not meeting the needs, taking more time to use, and not keeping the user satisfaction at the desired level, have to leave our daily life somehow because users no longer prefer these products (Lasi et al., 2014; Lee, I and Lee, K., 2015; Vaidya et al., 2018; Dalenogare et al., 2018; De Sousa Jabbour et al., 2018; views form authors, Infineon, 2019). 
Industry 4.0 and innovation actually meet at many points. Today perhaps one without the other is very unlikely to exist. Unless a business that wants to market a product or service related to machine learning offers an innovative solution, the product it develops may not be demanded at the expected level in the market. All innovative products can also be produced with an innovative perspective. many businesses had to move away from the physical environment and turned to digital. Today, big data, machine learning and artificial intelligence and many digital services have reminded us how much we actually need areas in epidemic situations. Therefore, people can use this industry 4.0 as an effective prevention technology against the big problems we face as a mass. Many of the developments that will occur as a result of Industry 4.0 will lead to a decrease in the demand for human labor. In this situation, it is important to develop an adequate innovation system that will allow new ideas for a manufacturing process owing to Industry 4.0 to come back to life without the need of humans (Chiarelloa et al., 2018; Vaidya et al., 2018; views form author; Infineon, 2019).

\section{Conclusion}

All kinds of decision-making processes of enterprises were directly affected by the developments related to Industry 4.0. At present time, while industry 5.0 has started to be talked about, all businesses have completed the adaptation process with industry 4.0 and have had to develop new business models that embrace technologies related to new innovative approaches. All these alternative technologies will be at the center of our lives with the perspective of industry 4.0 and innovation, and they will both change professions and end old needs and perhaps create new needs. As a society, researchers should follow the developments in this process individually and never stay away. Because while staying away from these technologies individually is a choice today, it may become a necessity even for these individuals tomorrow. Due to this influence, studies examining technologies on data and information management have gained importance humans (Chiarelloa et al., 2018; Dalenogare et al., 2018; Vaidya et al., 2018; views form author, Infineon, 2021). Thanks to the studies and literature researches, it has been observed that data mining techniques are used in subjects such as digital marketing, customer relations and the use of smart systems. With the increase in online shopping in recent times, studies on this subject have also increased. As a result, many data about customers can be collected thanks to wired and wireless smart systems, as is the case today, and this data is stored in the clouds. With these stored data, a lot of information is obtained about product presentation, aisle placement and shelf arrangement. In addition to the shopping data of the customers, social media shares regarding their internet browsing data and comments about the product service are also used as important data in this subject.

\section{Acknowledge}

I would like to thank the business officials, business employees and experts who helped me within the scope of the research by sharing their valuable information.

\section{References}

Douaioui, K., Fri, M., Mabroukki, C. and Semma, E. A. (2018). The Interaction between Industry 4.0 and Smart Logistics: Concepts and Perspectives. 11th International Colloquium of Logistics and Supply Chain Management LOGISTIQUA
Abele, E. and Reinhart, G. (2011). Zukunft der Produktion, Carl Hanser Verlag GMBH \& München

Adolph, S., Tisch, M. and Metternich, J. (2014). Challenges and approaches to competency development for future production. Educ. Altern. 12, 1001-1010.

Aheleroff, S., Xua , X., Lua, Y., Aristizabalb, M., Velásquez, J.P., Joab, B. and Valenciab, Y. (2020). IoT-enabled smart appliances under industry 4.0: A case study, Advanced Engineering Informatics, 43, 101043.

Amaral, A., Jorge, D. and Peças, P. (2019). Small Medium Enterprises And Industry 4.0: Current Models' Ineptitude And The Proposal Of A Methodology To Successfully Implement Industry 4.0 In Small Medium Enterprises. Procedia Manufacturing, 41, 11031110. doi:10.1016/j.promfg.2019.10.039

Alborzi, M. and Khanbabaei, M. (2016). Using data mining and neural networks techniques to propose a new hybrid customer behaviour analysis and credit scoring model in banking services based on a developed RFM analysis method. International Journal of Business Information Systems, 23(1), 1-22.

Bahrin, M.A.K., Othman, M.F., Azli, N.H.N. and Talib, M.F. (2016). Industry 4.0: a review on industrial automation and robotic, Jurnal Teknologi, 78, 6-13.

Bauer, W., Hämmerle, M., Schlund, S. and Vocke, C. (2015). Transforming to a hyper-connected society and economy towards an "Industry 4.0.". Procedia Manuf. 3, 417-424. https://doi.org/10.1016/j.promfg.2015.07.200.

Bravi, L. and Murmura, F. (2021). Industry 4.0 enabling technologies as a tool for the development of a competitive strategy in Italian manufacturing companies, Journal of Engineering and Technology Management. April-June 2021, 60, DOI: 10.1016/j.jengtecman.2021.101629.

Bruhn, M. and Hadwich, K. (2017). Dienstleistungen 4.0, Springer Fachmedien Wiesbaden, Wiesbaden, 2017.

Cedeño J.M.V., Papinniemi J., Hannola L., Donoghue I., 2018. Developing smart services by internet of things in manufacturing business. LogForum 14 (1), 59-71. http://dx.doi.org/10.17270/J.LOG.2018.268.

Culotta, A. and Cutler, J. (2016). Mining Brand Perceptions from Twitter Social Networks. Marketing Science, 35(3) ,343-362.

Chiarello, F., Trivelli, L., Bonaccorsi, A. and Fantoni, G. (2018). Extracting and mapping industry 4.0 technologies using wikipedia. Computers in Industry, 100, 244-257. doi:10.1016/j.compind.2018.04.006.

Dalenogare, L. S., Benitez, G. B., Ayala, N. F. and Frank, A. G. (2018). The expected contribution of Industry 4.0 technologies for industrial performance. International Journal of Production Economics. doi:10.1016/j.ijpe.2018.08.019.

De Sousa Jabbour, A. B. L., Jabbour, C. J. C., Foropon, C., and Godinho Filho, M. (2018). When titans meet - Can industry 4.0 revolutionise the environmentally-sustainable manufacturing wave? The role of critical success factors. Technological Forecasting and Social Change, 132, 18-25. doi:10.1016/j.techfore.2018.01.017.

\section{8, (128-132). Morocco:}

IEEE.

doi: 10.1109/LOGISTIQUA.2018.8428300.

Duysak, H., Ozkaya, U., \& Yigit, E. (2021). Determination of the Amount of Grain in Silos with Deep Learning Methods 
Based on Radar Spectrogram Data. IEEE Transactions on Instrumentation and Measurement.

Duxbury, T. (2012). Creativity: Linking Theory and Practice for Entrepreneurs. Technology Innovation Management Review, 2(8), 10-15.

Dima, A. (2021). Kfactory Short history of manufacturing: from Industry 1.0 to Industry 4.0 , https://kfactory.eu/shorthistory-of-manufacturing-from-industry-1-0-to-industry-4-0/ (Access Date: 21.05.2021).

Enyoghasi, C. and Badurdeen, F. (2021). Industry 4.0 for sustainable manufacturing: Opportunities at the product, process, and system levels, Resources, Conservation and Recycling, doi: 10.1016/j.resconrec.2020.105362.

Ganzarain, J. and Errasti, N. (2016). Three stage maturity model in SME's towards industry 4.0, J. Ind. Eng. Management.

Gartner Group (2017). Advanced Technology Research Note 2017, https://www.gartner.com/technology/research/, (Access Date: 12.04.2021).

Gerbert, P., Lorenz, M., Russmann, M., Waldner, M., Justus, J., Engel, P., and Harnisch, M. (2015). Industry 4.0: The Future of Productivity and Growth in Manufacturing Industries. https://www.bcg.com/publications/2015/engineered_product s_project_business_industry_4_future_productivity_growth _manufacturing_industries.aspx, (Access Date: 12.04.2021).

Ghazavi, E., and Lotfi, M. M. (2016). Formulation of customers' shopping path in shelf space planning: A simulationoptimization approach. Expert Systems with Applications, 55, 243-254. doi:10.1016/j.eswa.2016.01.043.

Griva, A., Bardaki, C., Pramatari, K. and Papakiriakopoulos, D. (2018). Retail business analytics: Customer visit segmentation using market basket data. Expert Systems with Applications, 100, 1-16. doi:10.1016/j.eswa.2018.01.029.

Horváth, D. and Szabó, R. Z. (2019). Driving forces and barriers of Industry 4.0: Do multinational and small and medium-sized companies have equal opportunities? Technological Forecasting and Social Change, 146, 119132. doi:10.1016/j.techfore.2019.05.021.

Holubčík, M., Koman, G. and Soviar, J. (2021). Industry 4.0 in Logistics Operations, Transportation Research Procedia. 53, 282-288, DOI: 10.1016/j.trpro.2021.02.040.

Infineon. (2021). What you need to know about Big Data?

https://www.infineon.com/cms/en/discoveries/big-data-basics/ (Access Date: 20.03.2021).

Innovation Cycle, https://www.crf.org/crf/contact-us/68-skirballinnovation-center-2/1549-innovation-cycle,

(Access Date:21.05.2021)

Innovation Management, How do you Define Innovation and Make it Practical and Saleable to Senior Management? https://innovationmanagement.se/2008/01/07/how-do-youdefine-innovation-and-make-it-practical-and-saleable-tosenior-management/ (Access Date: 14.06.2021).

Inkermann, D., Schneider, D., Martin, N. L., Lembeck, H., Zhang, J., and Thiede, S. (2019). A framework to classify Industry 4.0 technologies across production and product development. Procedia CIRP, 84, 973-978. doi:10.1016/j.procir.2019.04.218

Jin, X., Wah, B. W., Cheng, X. and Wang, Y. (2015). Significance and Challenges of Big Data Research. Big Data Research, 2(2), 59-64. doi:10.1016/j.bdr.2015.01.006.

Kagerman, H. and Johannes, H. (2013). Recommendations for implementing the strategic initiative Industry 4.0, Final Report, Industry 4.0 WG.
Kamble, S. S., A. Gunasekaran, and S. A. Gawankar. (2018) Sustainable Industry 4.0 Framework: A Systematic Literature Review Identifying the Current Trends and Future Perspectives. Process Safety and Environmental Protection, $117,408-425$

Kamble, S. S., Gunasekaran, A. and Sharma, R. (2018). Analysis of the driving and dependence power of barriers to adopt industry 4.0 in Indian manufacturing industry. Computers in Industry, 101, 107-119. doi:10.1016/j.compind.2018.06.004.

Kaneko, Y. and Yada, K. (2016). Fractal Dimension of Shopping Path: Influence on Purchase Behavior in a Supermarket. Procedia Computer Science, 96, 1764-1771. doi:10.1016/j.procs.2016.08.225

Karl, A.H. B. and Nadarajah, D. (2019). Investigating the Relationship between Industry 4.0 and Productivity: A Conceptual Framework for Malaysian Manufacturing Firms Procedia Computer Science, 161,696-706. doi:10.1016/j.procs.2019.11.173.

Kurt, R. (2019). Industry 4.0 in Terms of Industrial Relations and Its Impacts on Labour Life. Procedia Computer Science, 158, 590-601. doi:10.1016/j.procs.2019.09.093.

Lasi, H., Fettke, P., Kemper, H.-G., Feld, T. and Hoffmann, M. (2014). Industry 4.0. Business \& Information Systems Engineering, 6(4), 239-242. doi:10.1007/s12599-014-03344.

Lee, I. and Lee, K. (2015). The Internet of Things (IoT): Applications, investments, and challenges for enterprises. Business Horizons, 58(4), 431-440. doi:10.1016/j.bushor.2015.03.008.

Lichblau, K., Sicht, V., Bertenrth, R., Blum, M., Bleider, M., Millack, A., Schmitt, K., Schmitz, E. and Schroeter, M. (2015). IMPULS - Industrie 4.0 Readiness, 0-77.

MAGG4. (2018). Endüstri 4.0 Demek, İnovasyon Demektir. Genç Nesil, Güncel İçerikler: https://magg4.com/endustri4-0-demek-inovasyon-demektir/, (Access Date:22.04.2021)

Marr, B. (2017). How BMW Uses Artificial Intelligence And Big Data To Design And Build Cars Of Tomorrow. Forbes: https://www.forbes.com/sites/bernardmarr/2017/08/01/howbmw uses-artificial-intelligence-and-big-data-to-design-andbuild-cars-oftomorrow/\#3e36a06d2b91, (Access Date: 12.04.2021).

Morrar, R., Arman, H. and Mousa, S. (2017). The Fourth Industrial Revolution (Industry 4.0): A Social Innovation Perspective. Technology, Innovation Management Review, 7(11), 12-21.

Nakagawa, E. Y., Antonino, P.O., Schnicke, F.; Capilla, R.; Kuhn, T. and Liggesmeyer, P.(2021). Industry 4.0 reference architectures: State of the art and future trends, Computers \& Industrial Engineering. June 2021, 156, 107241, doi: 10.1016/j.cie.2021.10724.

Niemeyer, C. L., Gehrke, I., Müller, K., Küsters, D. and Gries, T. (2020). Getting Small Medium Enterprises started on Industry 4.0 using retrofitting solutions. Procedia Manufacturing, 45, 208-214. doi:10.1016/j.promfg.2020.04.096.

OECD. (2005). Oslo Kilavuzu: Yenilik Verilerinin Toplanması ve Yorumlanması İçin İlkeler, OECD. http://www.tubitak.gov.tr/tubitak_content_files/BTYPD/kila vuzlar/Oslo_3_TR.pdf, (Access Date: 24.05.2021).

Onu, P. and Mbohwa, C. (2019). Sustainable production: New thinking for SMEs, Journal of Physics: Conference Series, 1378, 022072, https://doi.org/10.1088/1742-6596/1378/2/ 022072 . 
Onu, P. and Mbohwa, C. (2019). Industrial energy conservation initiative and prospect for sustainable manufacturing, Procedia Manufacturing. 35 (2019) 546-551, https://doi. org/10.1016/j.promfg.2019.05.077.

Proença, D. and Borbinha, J. (2016). Maturity Models for Information Systems - A State of the Art, Procedia Computer Science, 100(2), 1042-1049.

Roblek, V., Mesko, M. and Krapez, A. (2016). A complex view of industry 4.0. Sage Open Journal, 6 (2), 1-11 (Sage Publications).

Rodrigues, F. and Ferreira, B. (2016). Product recommendation based on shared customer's behaviour. Procedia Computer Science, 100, 136-146.

Schmidt, R., Möhring, M., Härting, R.C., Reichstein, C., Neumaier, P. and Jozinović, P. (2015). Industry 4.0potentials for creating smart products: empirical research results, June, International Conference on Business Information Systems, Springer, Cham, 2015, 16-27

Schumacher, A., Erol, S. and Sihn, W. (2016). A Maturity Model for Assessing Industry 4.0 Readiness and Maturity of Manufacturing Enterprises, Procedia CIRP, 52, 161-166.

Spath, D., Ganschar, O., Gerlach, S., Hämmerle, M., Krause, T. and Schlund, S. (2013). Produktionsarbeit der ZukunftIndustrie 4.0. (Stuttgart).

Tanaka, T., Hamaguchi, T., Saigo, T. and Tsuda, K. (2017). Classifying and Understanding Prospective Customers via Heterogeneity of Supermarket Stores. Procedia Computer Science, 112, 956-964.

Telukdarie, A., Buhulaiga, E., Bag, S., Gupta, S. and Luo, Z. (2018). Industry 4.0 implementation for multinationals. Process Safety and Environmental Protection, 118, 316-329. doi:10.1016/j.psep.2018.06.030.

Tiwari, K. and Khan, M. S. (2020). Sustainability Accounting and Reporting in the Industry 4.0. Journal of Cleaner Production, 120783. doi:10.1016/j.jclepro.2020.120783.

The Cycle of Innovaton, https://dok5.nl/en/the-cycle-ofinnovation/ (Access Date:21.05.2021).

Trappey, A. J. C., Trappey, C. V., Hareesh Govindarajan, U., Chuang, A. C. and Sun, J. J. (2017). A review of essential standards and patent landscapes for the Internet of Things: A key enabler for Industry 4.0. Advanced Engineering Informatics, 33, 208-229. doi:10.1016/j.aei.2016.11.007.

Vishal A. and Vinodh, S. (2021). Analysis of Industry 4.0 challenges using best worst method: A case study, Computers \& Industrial Engineering. September 202, 159, doi: 10.1016/j.cie.2021, 1074- 1087.

Vaidya, S., Ambad, P. and Bhosle, S. (2018). Industry 4.0 - A Glimpse. Procedia Manufacturing, 20, 233-238. doi:10.1016/j.promfg.2018.02.034.

Vincent, O. R., Makinde, A. S., Salako, O. S. and Oluwafemi, O. D. (2018). A self-adaptive k-means classifier for business incentive in a fashion design environment. Applied Computing and Informatics, 14(1), 88-97.

Vishal A. and Vinodh, S. (2021). Analysis of Industry 4.0 challenges using best worst method: A case study, Computers \& Industrial Engineering. September 202, 159, DOI: $10.1016 /$ j.cie.2021, 1074- 87,

Vyas, K. (2018). How the First and Second Industrial Revolutions Changed Our World. Interesting Engineering: https://interestingengineering.com/how-the-first-andsecondindustrial-revolutions-changed-our-world, (Access Date: 12.04.2021).
What is Innovation?, https://innolytics-innovation.com/what-isinnovation/ (Access Date: 13.05.2021).

Weng, C. H. (2016). Identifying association rules of specific later-marketed products. Applied Soft Computing, 38, 518529.

Xu, L. D., Xu, E. L. and Li, L. (2018). Industry 4.0: State of the Art and Future Trends. International Journal of Production Research, 56(8), 2941-2962. doi:10.1080/00207543.2018.1444806.

Yao, X., Zhou, J., Zhang, J. and Boer, C.R. (2017). From intelligent manufacturing to smart manufacturing for industry 4.0 driven by next generation artificial intelligence and further on. In: 2017 5th International Conference on Enterprise Systems, vols. 22-24. IEEE, Beijing, China. Sept. 2017.

Yu, Y., Zhang, J. Z., Cao, Y., and Kazancoglu, Y. (2021). Intelligent transformation of the manufacturing industry for Industry 4.0: Seizing financial benefits from supply chain relationship capital through enterprise green management, Technological Forecasting \& Social Change. November 2021, 172, doi:10.1016/j.techfore.2021.120999.

Zheng, P., Chen, C.-H. and Shang, S. (2019). Towards an automatic engineering change management in smart product-service systems - A DSM-based learning approach. Advanced Engineering Informatics, 39, 203-213. doi:10.1016/j.aei.2019.01.002. 